\title{
Political Strategy on Border Areas in Indonesia to Combat Human Trafficking
}

\author{
Rr. Erika Purwa Andini ${ }^{1)}$, Adibah Rasikhah Amanto ${ }^{2)}$, Gigich Ilmy Al Bonadi ${ }^{3)}$. \\ Faculty of Cultural Science ${ }^{1)}$, Faculty of Medicine ${ }^{2)}$, Faculty of Social and Political Science ${ }^{3)}$, Universitas \\ Gadjah Mada - Indonesia
}

\begin{abstract}
Indonesia is the largest archipelago country in the world with 17,504 number of islands, whilst the extent area is about 1,910,931, $32 \mathrm{~km} 2$. Besides, Indonesia has various culture tribes composition for about 1,340 tribes spread all around Indonesia. From those data can be inferred that Indonesia is a big multicultural country. However this condition become one of the barriers towards Indonesian government in managing the socio-political system of Indonesia, particularly in frontier areas. Border management orientation is divided into two approach, security area orientation and welfare orientation. First orientation has focused on the government effort to keep state sovereignity through military defense, whilst the second one has intention to improve the welfare of people in frontier areas. Indonesia border management orientation yet seems have not maximized, evidenced by the existence of problems in the frontier areas that have not resolved until today. One of the unsolved problem exist today is human trafficking in frontier areas. There are three major factors causing the number of human trafficking in Indonesia is in high level according to data from the International Organization for Migration (IOM), the first is because the amount of human resources in Indonesia is very abundant but not all well-educated, the second, Indonesia is one of the biggest tourist destination in the world, and the last is Indonesia has a stategic geographical area for bussines enterprises in world trading. The problem of human trafficking in Indonesia frontiers listed in regulation of national frontiers management agency number 23 in 2014 about state frontier management master plan in 2014 to 2019 which will be assessed by two paradigms, paradigm of state security and human security. These studies will illustrate the effectiveness implementation of government regulations in frontier areas to decrease the number of human trafficking. Muchless, these studies can also be a reference for goverments in order to revise laws and implement the regulation.
\end{abstract}

Keywords: Political Strategy, the frontier regions, human trafficking.

\section{Introduction}

Indonesia merupakan negara kepulauan terbesar di dunia dengan jumlah pulau mencapai 17.499 , luas wilayah perairan mencapai 5,8 juta $\mathrm{km} 2$, dan panjang garis pantai mencapai $81.900 \mathrm{~km} 2$. Dua pertiga dari luas wilayah Indonesia berupa laut. Indonesia berbataskan laut dengan sepuluh negara, yakni Malaysia, Singapura, Filipina, India, Tailand, Vietnam, Republik Palau, Australia, Timor Leste, dan Papua Nugini. Adapun wilayah darat Indonesia berbatasan langsung dengan tiga negara, yaitu Malaysia, Papua Nugini, dan Timor Leste dengan keseluruhan panjang garis perbatasan darat adalah $2914,1 \mathrm{~km}$. Selain wilayah yang luas, Indonesia juga memiliki posisi geografs yang strategis (Marwasta, 2016).

Perbatasan negara merupakan manifestasi utama kedaulatan wilayah suatu negara. Perbatasan suatu negara mempunyai peranan penting dalam penentuan batas wilayah kedaulatan, pemanfaatan sumber kekayaan alam, dan menjaga keamanan serta keutuhan wilayah. Perbatasan negara dalam banyak hal ditentukan oleh proses historis, politik, dan hukum nasional serta internasional (Moeldoko, 2014). Tangkilisan (2013) mengatakan bahwa istilah perbatasan memiliki dua pengertian, yaitu boundaries dan frontiers. Dalam konteks boundaries, perbatasan merupakan garis pemisah wilayah antarnegara. Adapun dalam konteks frontier, perbatasan lebih merujuk pada jalur (zones) yang membentang dan memisahkan dua wilayah egara.

Kawasan perbatasan menjadi wilayah yang "sexy", baik dalam konteks internal maupun eksternal (internasional). Beberapa isu yang senantiasa menjadi wacana di wilayah perbatasan adalah: (a) potensi invasi ideologi dan budaya asing; (b) potensi kejahatan lintas negara (trans-national crimes); (c) pembalakan liar (illegal logging); (d) penangkapan ikan secara ilegal (illegal fshing); (e) eksploitasi sumber daya alam secara ilegal; (f) perdagangan manusia (human trafficking), terutama perempuan dan anak-anak; (g) imigran gelap 
(illegal immigrants); (h) penyelundupan manusia (people smuggling); (i) peredaran narkotika; (j) jalan masuk para teroris serta perompak; dan (k) konfik sosial budaya (Marwasta, 2016).

Berdasarkan paparan diatas mengenai perbatasan dan berbagai prmasalahanya, penelitian ini lebih membahas mengenai penanganan human trafficking di perbatasan Indonesia yang ditinjau dari UU No 23 Tahun 2014. Topik permasalahan ini dipilih karena maraknya kasus human trafficking di Indonesia khususnya di wilayah perbatasan, namun permasalahan ini kurang terekspose oleh pemerintah dan masyarakat Indonesia.

\section{Dinamika Permasalahan Perbatasan di Indonesia}

Hampir semua kawasan perbatasan Indonesia adalah daerah tertinggal yang kondisinya sangat memprihatinkan sebagai wajah luar negara. Selama ini kawasan perbatasan dikelola dengan mengedepankan pendekatan keamanan (safety belt approach) sehingga pembangunan sosial ekonomi menjadi terabaikan. Pemerintah Pusat menyadari seriusnya permasalahan ini, dan sejak 28 Januari 2010 telah membentuk Badan Nasional Pengelola Perbatasan (BNPP) sebagai institusi koordinasi dan implementasi program-program pemerintah untuk membangun kawasan perbatasan (The Partnership for Governance Reform, 2011). Namun pada akhirnya permasalahan ini tetap belum terselsaikan dengan baik. Hal ini dibuktikan dalam jurnal The Partnership for Governance Reform yang membahas mengenai kebijakan kawasan perbatasan Indonesia. dalam jurnal tersebut membahas permaslahan perbatasan di Indonesia, untuk menjelaskan permasalahan tersebut maka dapat dilihat tabel berikut:

\begin{tabular}{|c|c|c|c|c|c|c|}
\hline & & \multicolumn{5}{|c|}{ Aspek } \\
\cline { 3 - 7 } No & $\begin{array}{c}\text { Daerah } \\
\text { Perbatasan }\end{array}$ & $\begin{array}{c}\text { Rendahnya } \\
\text { SDM }\end{array}$ & $\begin{array}{c}\text { Rendahnya } \\
\text { Sarana } \\
\text { Prasarana }\end{array}$ & $\begin{array}{c}\text { Rendahnya } \\
\text { Tingkat } \\
\text { Kesehatan }\end{array}$ & $\begin{array}{c}\text { Rendahnya } \\
\text { Tingkat } \\
\text { Pendidikan }\end{array}$ & $\begin{array}{c}\text { Rendahnya } \\
\text { Tingkat } \\
\text { Ekonomi }\end{array}$ \\
\hline 1 & $\begin{array}{c}\text { Kalimantan } \\
\text { Timur }\end{array}$ & $\checkmark$ & $\checkmark$ & $\checkmark$ & $\checkmark$ & $\checkmark$ \\
\hline 2 & $\begin{array}{c}\text { Kalimantan } \\
\text { Barat }\end{array}$ & $\checkmark$ & $\checkmark$ & $\checkmark$ & $\checkmark$ & $\checkmark$ \\
\hline 3 & Riau & $\checkmark$ & $\checkmark$ & $\checkmark$ & $\checkmark$ & $\checkmark$ \\
\hline 4 & Papua & $\checkmark$ & $\checkmark$ & $\checkmark$ & $\checkmark$ & $\checkmark$ \\
\hline 5 & NTT & $\checkmark$ & $\checkmark$ & $\checkmark$ & $\checkmark$ & $\checkmark$ \\
\hline
\end{tabular}

Tabel 1. Permasalahan di wilayah perbatasan Indonesia

Berdasarkan tabel tersebut maka dapat ditarik kesimpulan bahwa permasalahan perbatasan Indonesia terdapat beberapa permaslahan yang sama, yaitu rendahnya SDM, rendahnya tingkat kesehatan, rendahnya tingkat pendidikan, dan rendehnya tingkat ekonomi. namun hal ini tidak menutup kemungkinan mengenai permasalahan permasalahan lainnya. Permasalahan permasalahan inilah yang mendorong tingginya angka human trafficking di daerah perbatasan.

\section{Human Trafficking Overview}

In today's age of globalization, human beings have become commodities crossing national and international borders. As they do, they are vulnerable to being exploited through coercion, deceit, or force in their home countries or abroad. Desperation to migrate in the hope of a better life in the future renders migrant highly vulnerable to being trafficked, some willingly, to accept exploitative work (Hanley, Oxman-martinez, Lacroix, \& Gal, 2006). According to article 3, paragraph (a) of the Protocol to Prevent, Suppress and Punish Trafficking in Persons defines Trafficking in Persons as the recruitment, transportation, transfer, harbouring or receipt of persons, by means of the threat or use of force or other forms of coercion, of abduction, of fraud, of deception, of the abuse of power or of a position of vulnerability or of the giving or receiving of payments or benefits to achieve the consent of a person having control over another person, for the purpose of exploitation. Exploitation shall include, at a minimum, the exploitation of the prostitution of others or other forms of sexual exploitation, forced labour or services, slavery or practices similar to slavery, servitude or the removal of organs. Studies have shown that human trafficking is linked to the economic disparity between countries with both poverty and 
migration as the driving forces behind international trafficking in persons (International Labor Organization, 2005). According to Global Slavery Index an estimated 29.8 million people live in modern slavery today, which include slavery, slavery-like practices (such as debt bondage, forced marriage and sale, or exploitation of children), forced labor, and other practices described in key international treaties. Indonesia is known as country with highly risk of human trafficking both in international and domestic area.

Regarding in its position, border area is a gate of country's soveregnity conveying reflection, image and first impression of how that county is. Border area is mostly well known as left behind area of its development in many sectors, muchless in its society's welfare.

To combat human trafficking in border areas there are two basic security approaches needed to create comprehensive development strategy. The first is state ecurity approach which including whole sectors such as fortress, security, environtment, politics, and social culture. And the second is human security in which focusing on empower the people around border areas. However we suppose to count heavily in this second factor as mentioned the importance of human security below by some social expert.

Pratikno (2009) mentioned three approaches or ideologies of human security:

1. Approach which focusing on human right

2. Approach which emphasize on human safety

3. Approach which emphasize on sustainable development attempts. This approach is related to seven human development dimension as mentioned in Human Development Report by UNDP.

However Cornelis Lay (2009) explained six kinds of human right which related to threat against human safety:

1. Right of individual basic, including right to being alive, having the same position in the name of law, protection against race, religion, ethnic, and gender discrimination.

2. Legality right, including access to have law protection and get the legally process of law.

3. Civil freedom, including freedom of thinking, speech, and doing devotional rituals as what they believe.

4. Right of basic necessity, including access to food, health warranty, and fulfilled, minimum life necessity.

5. Economic right, including right to have job, recreation and right of social warranty.

6. Political right, including right to choose and being chosen in public position participate in state management.

\section{Indonesia's Law Border Analysis}

Indonesia government Law No. 23 of 2014 on Border Areas Regulation establish definition about border areas, this is included in subsection 361. This subsection mentioned that border area are outermost districts which directly neighbouring with another countries. To regulate border areas the central government have authority in form of management and utilization these areas, which include detail planning of spatial determination, management and utilization permission, and construction of infrastructure around areas.

Central government in running authorities is helped by the governor, in which their duty is to coordinate construction implementation of border areas under central goverment's guidance. However to ease the duty of governor, a mayor city, leader under governor in Indonesia's hirarchial structure also assist district leaders, somewhat under mayor city assistance around border areas. This division of duties are purposed to develop border areas, so it would not be left behind compare to another areas.

The smallest unit of government which directly in touch with society's in border areas is district leaders, in which they are formed by local law after being approved by national ministry. Structural organization, job division, terms and conditions in electing district leaders have been regulated by ministry's law under the command of government state apparatus affairs minister.

District leaders' duties tend to implement direct service such as immigration post across borders service in isolated area which sometimes considered not efficient if it is held by the ministry government or non government organization itself.

Law No. 23 of 2014 on Border Areas Regulation commonly having objectives about "national strategic importance", which having importance of preserving Indonesia integrity and sovereignity, improving society's 
welfare in border areas, outermost islands, a nd certain regions. To easier the understanding of government's coodrination in border areas we present structural organization chart below:

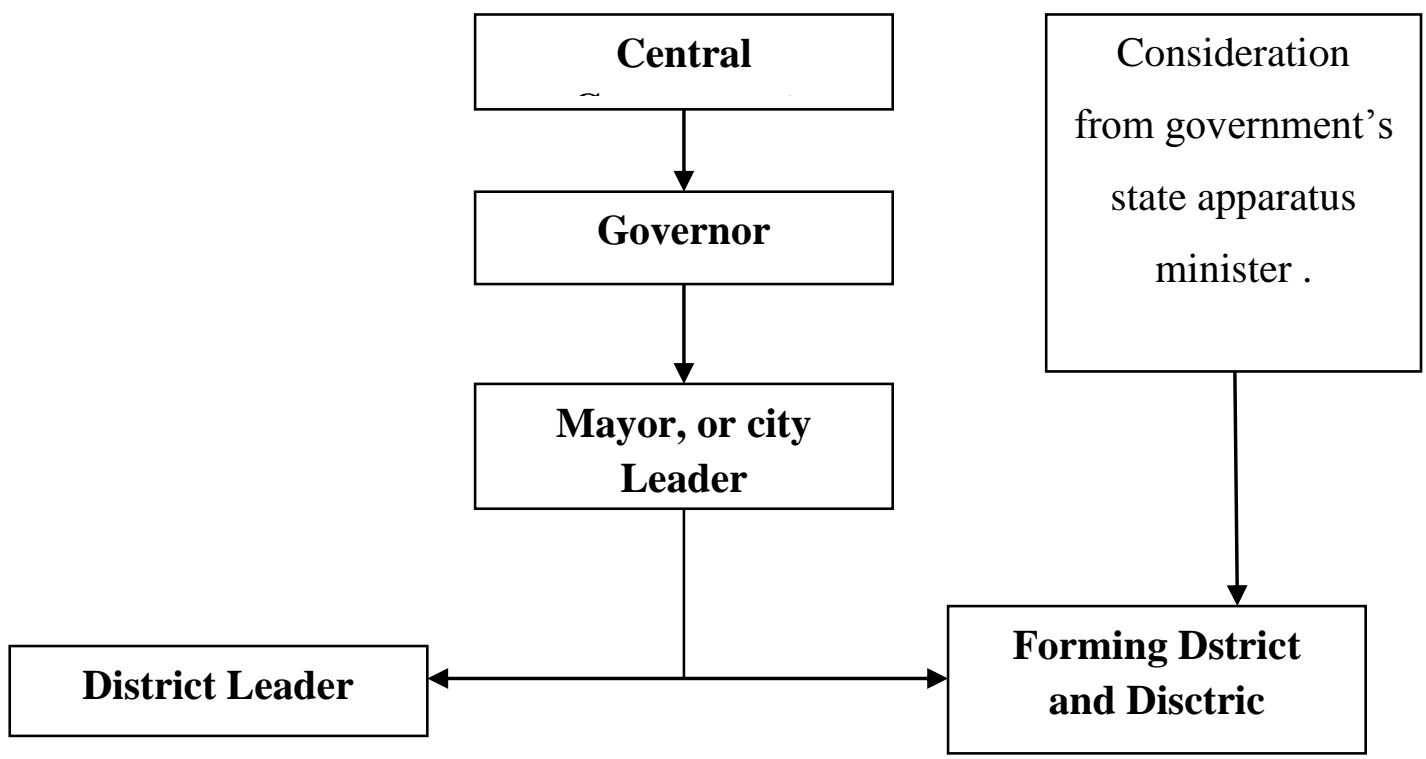

Chart Description. Government coordination in borders

In border areas of Indonesia central government use the relation of central and border areas through decentralization in frame of unity. A unitary state is "Habitual excersise of supreme legislative authority by one power" (Strong, 1960) whilst the definiton of unitary state divided into two forms (Kaho, 2012):

1. Unitary state with centralization system, in which all the state instruments directly regulated and managed by central government, so the region leaders technically undertake the command from them.

2. Unitary state with decentralization system, in which the head of region given chance and authority to regulate and manage their own governmental stuffs, which called autonomus region.

According to that classification, Indonesia follows the form of decentralization unitary state, like mentioned in Law No. 23 of 2014 on Border Areas Regulation.

The choice of decentralization form of course have an important role in managing border areas, in this research analysis the existence of decentralization in Indonesia in form of unity is important because Indonesia is a country with various kinds of diversity, the amount of population is about 222.461 .686 people (Ritongga, 2015). This large amount of population composed of 2.500 languages or twice bigger than the amount of tribes which reach number 1.340 (National Statistics Organization, 2010). Of course this magnified amount of population and diversity should be followed by fair policy which protect, preserve and regulate the whole layers of society. On the other hand, geographical area of Indonesia is archipelago, therefore desentralization border areas management is needed to decrease the number of human trafficking that mostly happen in these areas in Indonesia.

There are a lot of ways to improve society's welfare in border areas, one of which by upgrading the quality of social organization that manage the society's around there. However this quality also should be supported by organizational coordination both in vertical and horizontal's perspectives. 


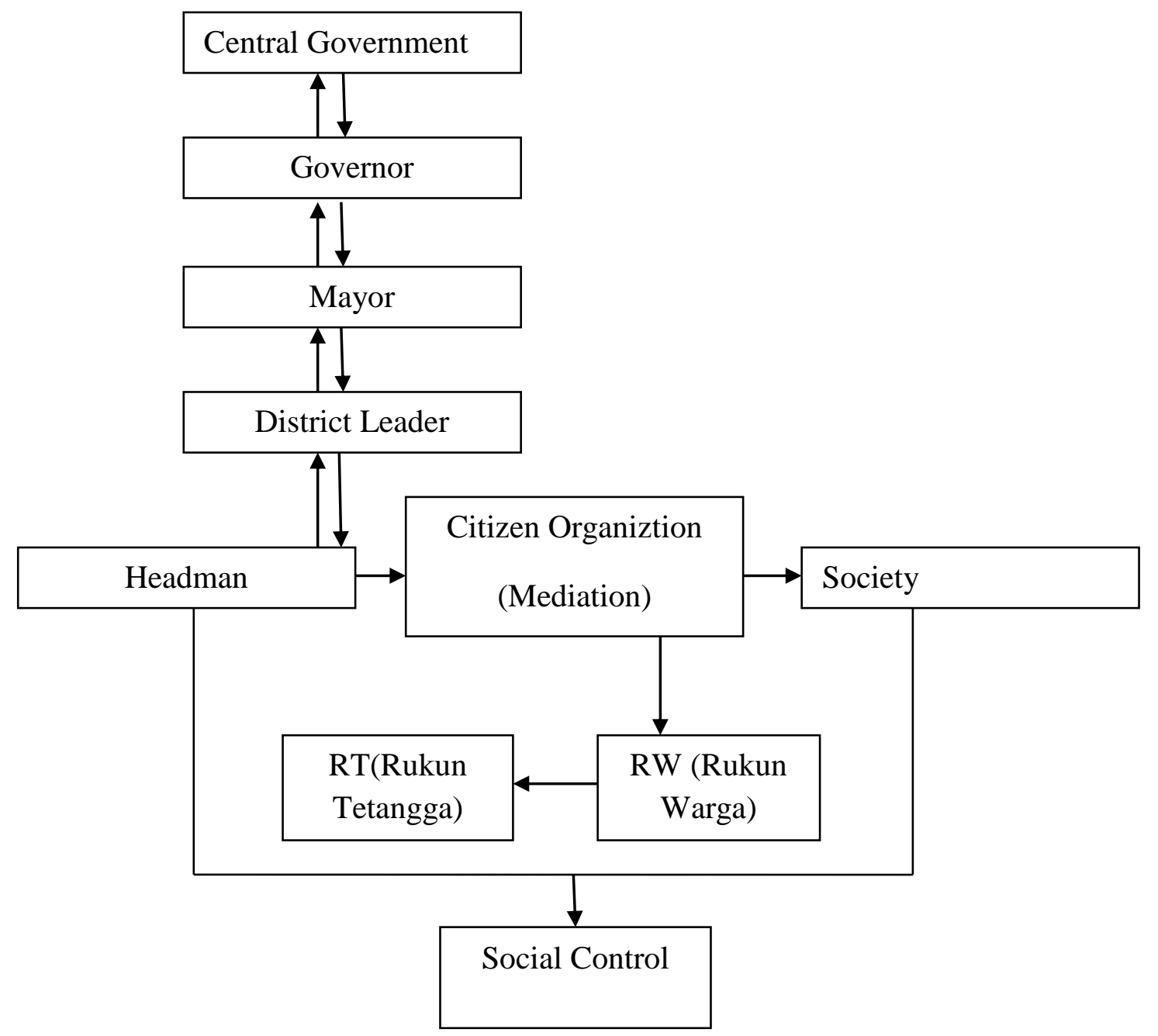

Chart 2. Line coordination central from government until RT, Rukun tetangga, smallest unit in governmental structure

After analyzing the coordination line above, the more action that we need is analyze their important role and relations which need to be improved, here are the lists:

1. Consultative Relation:

Is a relation among society's instituiton and local leaders which should develop immensely colloquy principle.

2. Coordinative Relation:

Coordinataive realtion in society's position holds important role to improve eager of participation around them, because coordinative relation is an index of group accomplishment regularly and unitary of acts to reach the same vision.(Sufian, 1995)

3. Partnership Relation:

Partnership relation could be portrayed from social institution with district leader or mayor. In a concrete form is on financing events by social institutions (Rauf, 2015). This relation will improve social relation among societies and develop the infrastructures.

4. Deliberative Relation

Deliberative Relation according to Widodo (2001) is a relationship in the process of take and give among groups in society about the nature of a policy through a debit, discussion, dialogue and consensus colloquy process. This relationship could be applied at all layers of civil society, because these aspects will form the culture of governance in society.

5. Mediation and social control 
In order to make all relations well organized, mediation and social control are needed. The function of mediation is to be mediator and liaison between the actors, so the internal interest could be accommodated. While the function of social control is overseeing the actors' performance in order to avoid abusive functions and duties. Mediation itself means a neutral third person in the dispute that exists (Soekanto, 2003), whereas social control is the public security of government behavior nets (Soekanto, 2001).

By implementing state and human security in border areas in which supported with undertaking government's policy with fully responsible supervision from all layers of government start from central government until RT, it is hoped to be very effective way in combating human trafficking in border areas.

\section{Conclusion}

According to Indonesia border area analysis through government Law No. 23 of 2014 on Border Areas Regulation will directly impact to hold down the numbers of human trafficking in Indonesia. We have found this logic in that goverment law: approach which focusing on human right, approach which emphasize on human safety, and approach which emphasize on sustainable development attempts. This approach is related to seven human development dimension as mentioned in Human Development Report by UNDP (Pratikno, 2009).

The government Law No. 23 of 2014 on Border Areas Regulation is obviously suitable with social condition and geographical area in Indonesia, however it would be much better if the real implementation done effectively and efficiently in undertaking. Moreover, the government support to the running of social institution is neede because from them, society's around would be easily to communicate and interact. This good adcocay through communication and interaction will reduce the number of human trafficking.

\section{Bibliography}

[1] Indonesia Government Law. (Tittle of the Rules), Number 23, 2014.

[2] Intern Ministry. "Tittle of Rule”. Number 5, Section 18, 2007.

[3] Kaho, Josef Riwu. Analisa Hubungan Pusat dan Daerah Di Indonsia. PolGov Fisipol UGM, 2012.

[4] Human Trafficking Definition. Protocol Palermo Article 3. UNODC. 2012.

[5] Marwasta, Djaka. 2016. Pendampingan Pengelolaan Wilayah Perbatasan Di Indonesia: Lesson Learned Dari KknPpm Ugm Di Kawasan Perbatasan”. Indonesian Journal of Community Engagement Vol. 01, No. 02, Maret 2016.

[6] Moeldoko, 2014. "Kompleksitas Pengelolaan Perbatasan: Tinjauan dari Perspektif Kebijakan Pengelolaan Perbatasan Indonesia" dalam Makalah Seminar "Pengelolaan Sumber Daya Alam dalam Perspektif Ketahanan Nasional”. Universitas Tanjungpura Pontianak, tanggal 8 Mei 2014. Tidak dipublikasikan.

[7] Na'im, Akhsan. Kewarganegaraan, Suku Bangsa, Agama, dan Bahasa sehari-hari Penduduk Indonesia Katalog BPS, 2010.

[8] Rauf, Rahyunir. Lembaga Kemasyarakatan Indonesia. Zanafa Publishing, 2015.

[9] Ritongga, Rizali. Kebutuhan Data Ketenagakerjaan Untuk Pembangunan Berkelanjutan. BPS, 2015.

[10] Soekanto. Sosiologi Suatu Pengantar, Cetakan Ke enam. Rajawali Grafindo Persada, 2003.

[11] Soekanto. Sosiologi Suatu Pengantar. Rajawali Grafindo Persada, 2001.

[12] Strong, C.F. Modern Political Institutions: An Introduction to the Comparative Study of Their History and Existing Form. Sidgwich and Jackson, 1960.

[13] Tangkilisan, Yuda B. 2013. "Indonesia dan Masalah Perbatasan: Beberapa Masalah dalam Perkembangan Daerah Tapal Batas sebagai Bagian Perekonomian Nasional dari Perspektif Sejarah" dalam Jurnal Kajian Sejarah \& Pendidikan Sejarah. No.1. Vol.1. Edisi Maret 2013.

[14] The Partnership for Governance Reform. 2011. “Kebijakan Pengelolaan Kawasan Perbatasan”. Partnership Policy Paper No. 2/2011

[15] Sufian. Administrasi, Organisasi, dan Manajemen. UIE Press, 1995.

[16] Widodo, Joko. Good Governance. Insan Cendekia, 2001. 